\title{
Journal of Contemporary History
}

This quarterly review, edited by Walter Laqueur (Director of the Institute of Contemporary History, London) and George Mosse (Professor of History, University of Wisconsin) is the first journal in any language to be entirely devoted to contemporary history. It will deal not only with political history but also with the history of ideas and movements, and of the social forces of our time. The Journal will try to bridge the widening gap between the specialist and the general student of history or indeed the layman.

The first issue presents a symposium on the theme of

INTERNATIONAL FASCISM 1920-45

with articles by

Sir Llewellyn' Woodward, The study of contemporary History; Adrian Lyttelton, The 'second wave' of Italian fascism; Professor Robert Soucy, Fascism in France; Professor Hugh SetonWatson, Fascism right and left; Professor George Mosse, The origins of Fascism; Professor Eugen Weber, The Iron Guard in Rumania; Hugh Thomas, The Spanish Falange; Professor Ludwig Jedlicka, The Austrian Heimwehr; Dr. Gilbert Allardyce, Doriot; Paul Hayes, Quisling; Erwin Oberländer, The Russian Fascist Party.

The second issue will have as its theme the left-wing intelligentsia between the two world wars, and the following number will present a re-assessment of the situation in Europe on the eve of the first world war.

Each issue 15s. Annual subscription 50s.

Published by WEIDENFELD \& NICOLSON 20 New Bond Street Landon W1

\section{Scottish Journal of Political Economy}

Vol. III

NOVEMBER 1965

No. 3

The Need for a Regional Policy in a Common Market ....... Richard Bird Direct Overseas Investment in Nigeria 1953-65 .......... Ranald S. May Economics and the Problem of Method ................ S. Skinner Educational Costs and Local Government Structure in Scotland .. J. Sleeman Does Glasgow Overspill Cream Off the More Able? .. G. Jahoda and M. Green A Theory of Interest Rates or Asset Prices? ............... C. V. Brown The Reference of the Printing Wage Agreement to the Prices and Incomes Board

The Scottish Journal of Political Economy is published in February, June, and November, and is free to members of The Scottish Economic Society. Applications for membership should bo made to The Treasurer, Scottish Economic Society, 144 St. Vincent Street, Glasgow, C.2., enclosing the annual subscription of 35/- The Journal may also be obtained by non-members by ordering through any bookseller or direct from the publisher, Oliver \& Boyd, Tweedale Court, Edinburgh, 1, price $12 / 6$ per single copy. 